\title{
Day-night ammonium oxidation in an urban stream: the influence of irradiance on ammonia oxidizers
}

\author{
S. Bernal ${ }^{1,2,4,5}$, S. N. Merbt ${ }^{3,4,6}$, M. Ribot ${ }^{1,7}$, E. 0. Casamayor ${ }^{1,8}$, and E. Marti ${ }^{1,9}$ \\ ${ }^{1}$ Integrative Freshwater Ecology Group, Centre d'Estudis Avançats de Blanes, CEAB-CSIC, Accés a la Cala St Francesc 14, \\ 17300 Blanes, Spain \\ ${ }^{2}$ Department d'Ecologia, Facultat de Biologia, Universitat de Barcelona, UB, Diagonal 625, 08028, Barcelona, Spain \\ ${ }^{3}$ Swiss Federal Institute of Aquatic Science and Technology (EAWAG), Department of Environmental Toxicology, Überlandstrasse 133 \\ Postfach 611, 8600 Dübendorf, Switzerland \\ ${ }^{4}$ S. Bernal and S. N. Merbt contributed equally to this work.
}

\begin{abstract}
Efficient $\mathrm{NH}_{4}{ }^{+}$oxidation is a critical issue in human-impaired streams receiving high $\mathrm{N}$ loads from the effluent of wastewater treatment plants (WWTP). Archaeal (AOA) and bacterial (AOB) ammonia oxidizers are strongly photoinhibited in laboratory cultures, so we expected that light availability would affect the distribution of $\mathrm{AOA}$ and $\mathrm{AOB}$ and $\mathrm{NH}_{4}{ }^{+}$oxidation rates at the reach scale. We selected 2 contiguous reaches downstream of a WWTP input in La Tordera river (northeastern Spain) that strongly differed in canopy cover (open and shaded). Against expectations and despite significant differences in light availability, the 2 reaches showed similar abundance of AOA and AOB and similar daily rates of ecosystem respiration, gross primary productivity, and $\mathrm{NH}_{4}{ }^{+}$ oxidation. The abundance of ammonia oxidizers was not correlated with biomass in biofilms protected from light, whereas a positive relationship was found for light-exposed biofilms. This result suggests that biomass accrual could provide light protection to ammonia oxidizers in light-exposed biofilms. The contribution of $\mathrm{NH}_{4}{ }^{+}$oxidation to whole-reach $\mathrm{NH}_{4}{ }^{+}$uptake reached up to 89\%, indicating a high potential for $\mathrm{NH}_{4}{ }^{+}$oxidation in the 2 reaches. $\mathrm{NH}_{4}{ }^{+}$oxidation rates were similar between night and day, but their contribution to whole-reach $\mathrm{NH}_{4}{ }^{+}$uptake tended to be higher at night than during the day. Altogether, these findings highlight that environmental factors other than irradiance drive reach-scale $\mathrm{NH}_{4}{ }^{+}$oxidation in this urban stream.
\end{abstract}

Key words: ammonium oxidation, urban stream, biofilm, ammonia oxidizers, Archaea, Bacteria, photoinhibition

$\mathrm{NH}_{4}{ }^{+}$uptake at the reach scale depends on assimilatory (i.e., incorporation of $\mathrm{N}$ into biomass) and energy-yielding dissimilatory (i.e., $\mathrm{NH}_{4}{ }^{+}$oxidation) processes. Light availability has a positive influence on assimilatory $\mathrm{NH}_{4}{ }^{+}$uptake by photoautotrophs at the ecosystem scale (Mulholland et al. 2006). However, current understanding of the potential effects of natural irradiance on $\mathrm{NH}_{4}{ }^{+}$oxidation in aquatic ecosystems is limited. Oxidization of $\mathrm{NH}_{4}{ }^{+}$to $\mathrm{NO}_{2}{ }^{-}$is the first and rate-limiting step of nitrification and plays a pivotal role in aquatic biogeochemical cycles by linking $\mathrm{N}$ inputs ( $\mathrm{N}$ fixation and mineralization) and outputs $\left(\mathrm{NH}_{4}{ }^{+}\right.$oxidation, anammox). Ammonia-oxidizing bacteria (AOB) and archaea (AOA) are widely distributed in natural environments. These chemoautotrophs use $\mathrm{NH}_{4}{ }^{+}$as an energy source and the ammonia monooxygenase enzyme to transform $\mathrm{NH}_{4}{ }^{+}$into $\mathrm{NO}_{2}{ }^{-}$aerobically (Fernández-Guerra and Casamayor 2012). Investigators have shown that AOA and $\mathrm{AOB}$ are highly sensitive to light in laboratory studies based on batch cultures (French et al. 2012, Merbt et al. 2012). In particular, light exposure inhibits the growth of AOA completely even at low intensities and, unlike AOB, AOA growth does not recover once cultures are returned to dark conditions. The strong inactivation of AOA typically is attributed to adsorption of light by the oxygenated state of the $\mathrm{Cu}$-containing enzyme ammonia monooxygenase (Shears and Wood 1985, Hyman and Arp 1992, Walker et al 2010).

Vertical zonation of ammonia oxidizers has been observed in lakes and oceans, where $\mathrm{NH}_{4}{ }^{+}$oxidation occurs mainly in deep dark layers (Lomas and Lipschultz 2006, Beman et al. 2012, Small et al. 2013). This zonation could be explained by either competition of ammonia oxidizers with phytoplankton for available $\mathrm{NH}_{4}{ }^{+}$(Smith et al. 2014) or

E-mail addresses: ${ }^{5}$ sbernal@ceab.csic.es; ${ }^{6}$ To whom correspondence should be addressed, stephanie.merbt@eawag.ch; ${ }^{7}$ mribot@ceab.csic.es; ${ }^{8}$ casamayor @ceab.csic.es; ${ }^{9}$ eugenia@ceab.csic.es

DOI: 10.1086/691797. Received 26 May 2016; Accepted 9 February 2017; Published online 22 March 2017.

Freshwater Science. 2017. 36(2):272-283. ๑ 2017 by The Society for Freshwater Science. 
high susceptibility to light (Merbt et al. 2016). In streams, AOA and AOB are part of benthic microbial biofilm assemblages growing on submerged substrata and within the sediment (Merbt et al. 2011, Sonthiphand et al. 2013). Those ammonia-oxidizing communities can experience photoinhibition when biofilms developed naturally in the dark are experimentally exposed to light (Merbt et al. 2016). Thus, we hypothesized that irradiance could determine the spatial distribution of ammonia oxidizers and diel rates of $\mathrm{NH}_{4}{ }^{+}$ oxidation in stream ecosystems and, ultimately, could dictate in-stream $\mathrm{NH}_{4}{ }^{+}$oxidation at the reach scale. Spatial distribution of ammonia oxidizers and diel rates of $\mathrm{NH}_{4}{ }^{+}$ oxidation are important and widely unexplored aspects of nutrient biogeochemistry in streams.

Low-order streams frequently have shallow water depth and high transparency. These characteristics favor penetration of direct sunlight to stream substrata, which may limit the spatial distribution and activity of ammonia oxidizers. Photoinhibition could explain the variation in $\mathrm{NH}_{4}{ }^{+}$assimilatory uptake and $\mathrm{NH}_{4}{ }^{+}$oxidation across streams (Peterson et al. 2001), between streams differing in canopy cover (Sabater et al. 2000), or among seasons within a stream (Martí and Sabater 1996, von Schiller et al. 2008). Furthermore, irradiance can influence stream metabolic activity and thus, can regulate in-stream $\mathrm{NH}_{4}{ }^{+}$assimilatory uptake and $\mathrm{NH}_{4}{ }^{+}$oxidation at the scale of a day (Nelson and Conway 1979, Reuter et al. 1986). For instance, sunlight (and associated increase in temperature) enhances photosynthesis and $\mathrm{N}$ demand, which results in higher dissolved $\mathrm{O}_{2}$ (DO) and lower dissolved inorganic N (DIN) concentrations during the day than at night (Lupon et al. 2016). In turn, daytime increases in temperature and DO concentration may enhance the activity of ammonia oxidizers and, hence, increase $\mathrm{NH}_{4}{ }^{+}$oxidation rates (Warwick 1986, Gammons et al. 2011, Tourna et al. 2008). Alternatively, $\mathrm{NH}_{4}{ }^{+}$oxidation during the day may be limited by photoinhibition and high algal N demand (Risgaard-Peterson et al. 2004, Reuter et al. 1986, Smith et al. 2014). The extent to which these abiotic and biotic interactions could determine day-night changes in $\mathrm{NH}_{4}{ }^{+}$oxidation rates at reach scale is poorly understood.

The goal of our study was to examine the influence of natural irradiance on: 1) the abundance and distribution of ammonia oxidizers and 2) $\mathrm{NH}_{4}{ }^{+}$oxidation rates at reach scale. To this end, we used a combination of molecular genetics and biogeochemistry approaches to study 2 reaches that differed in canopy cover in a highly N-loaded stream. We measured the abundances of AOA and AOB in biofilms in sediments (epipsammic biofilms) and on submerged cobbles (epilithic biofilms) and combined those findings with day-night measurements of net and gross $\mathrm{NH}_{4}{ }^{+}$oxidation rates estimated based on constant rate $\mathrm{NH}_{4}{ }^{+}$additions at the reach scale. Given the severe photoinhibition experienced by ammonia oxidizers under laboratory conditions, we expected a negative influence of irradiance on the abun- dance of ammonia oxidizers and lower reach-scale $\mathrm{NH}_{4}{ }^{+}$ oxidation rates during the day than at night.

\section{METHODS}

Study site

Our study site was downstream from the input of the wastewater treatment plant (WWTP) of the village of Santa Maria de Palautordera (lat $41^{\circ} 41^{\prime} 3.47^{\prime \prime} \mathrm{N}$, long $2^{\circ} 27^{\prime}$ $\left.33.19^{\prime \prime} \mathrm{W}\right)$ in La Tordera River, a $3^{\text {rd }}$-order Mediterranean stream northeast of Barcelona, Spain. The WWTP lacks tertiary treatment, and therefore, its partial $\mathrm{NH}_{4}{ }^{+}$oxidation capacity results in an effluent with high $\mathrm{NO}_{3}{ }^{-}$and $\mathrm{NH}_{4}{ }^{+}$concentrations. In previous studies conducted at the same site, investigators found high in-stream $\mathrm{NH}_{4}{ }^{+}$oxidation evidenced by consistent decreases in $\mathrm{NH}_{4}{ }^{+}$concentration and increases in $\mathrm{NO}_{3}{ }^{-}$concentration along the stream (Merseburger et al. 2005, Ribot et al. 2012). In this stream, the epilithic biofilms contain high abundances of AOA and AOB, mainly Nitrosotalea devanaterra and Nitrosomonas europaea, which are highly sensitive to light (Merbt et al. 2012, 2015).

We selected two 100-m-long reaches 600 and $900 \mathrm{~m}$ downstream of the WWTP input. The reaches differed in the degree of canopy cover and presented contrasting in situ irradiance. The riparian canopy was dense at the upstream reach (hereafter, the shaded reach), and very sparse at the downstream reach (hereafter, the open reach). The 2 reaches had similar channel morphology and streambed substrata composition. The shaded reach was $3.9 \pm 0.7 \mathrm{~m}$ wide, and the streambed substrata consisted of $10 \pm 8 \%$ rocks, $55 \pm 9 \%$ cobbles, $16 \pm 12 \%$ gravel and $19 \pm 18 \%$ fine sediment. The open reach was $4.5 \pm 0.6 \mathrm{~m}$ wide and the streambed substrata consisted of $3 \pm 3 \%$ rocks, $74 \pm 3 \%$ cobbles, $9 \pm 2 \%$ gravel, and $14 \pm 7 \%$ fine sediment. The stream water column was $<10 \mathrm{~cm}$ deep in both reaches and had low turbidity.

\section{Field measurements}

At each reach, we measured discharge $(Q$, in $L / s)$ with slug additions of a conservative tracer $(\mathrm{NaCl}$; Gordon et al. 2004). We calculated stream channel width ( $W$, in $\mathrm{m}$ ) as the average of measurements at 7 evenly distributed sampling stations along each reach. Irradiance was measured at 20-min intervals over the study period by 5 data loggers (HOBO UA-002-64) evenly distributed along each reach. We calculated daily photosynthetically active radiation (PAR, in $\mathrm{mol} \mathrm{m}^{-2} \mathrm{~d}^{-1}$ ) by integrating averaged instantaneous irradiance data from the 5 data loggers over the daytime hours. We recorded DO concentration, water temperature, and atmospheric pressure at 5-min intervals at the top and at the bottom of each reach with $\mathrm{O}_{2}$ probes (HQ 30d; Hach, Loveland, Colorado). Deployments lasted $4 \mathrm{~d}$, and we used these measurements to characterize stream metabolism at each reach. 
We measured reach-scale gross and net $\mathrm{NH}_{4}{ }^{+}$oxidation rates based on short-term constant-rate additions of $\mathrm{NH}_{4} \mathrm{Cl}$ and a conservative tracer (i.e., $\mathrm{NaCl}$ ) (Webster and Valett 2006). We carried out 4 additions/reach (8 total), 2 during the day (starting at $1300 \mathrm{~h}$ ) and 2 at night (starting at $0100 \mathrm{~h}$ ) on 2 consecutive days (all in September 2013). Experimental additions resulted in $\mathrm{NH}_{4}{ }^{+}$concentrations close to $1.5 \mathrm{mg} / \mathrm{L}$ at plateau, an increase similar to that caused by the inputs of $\mathrm{NH}_{4}{ }^{+}$from the WWTP effluent (Merseburger et al. 2005, Merbt et al. 2011, Ribot et al. 2012). Before the addition, we measured electrical conductivity (EC) and temperature at the 7 sampling stations. We collected background water samples at each sampling station and used them to estimate reach-scale net $\mathrm{NH}_{4}{ }^{+}$oxidation rates. Once EC at the last station achieved plateau conditions (after $\sim 1.5 \mathrm{~h}$ ), we collected water samples and recorded EC and temperature at each sampling station. We collected water samples for both background and plateau conditions at the thalweg of the reach following a Lagrangian approach to ensure that the same parcel of water was sampled while travelling downstream (Writer et al. 2011). In this way, we minimized the potential effect of changes in water quality of the WWTP effluent on stream $\mathrm{N}$ concentrations during the experiment. We filtered water samples immediately through $0.7-\mu \mathrm{m}$ pore-size glass-fiber filters (Albet, Barcelona, Spain) and stored them on ice for further chemical analysis.

We characterized epilithic biofilms by measuring biomass, chlorophyll $a$ content (chl $a$ ), and both archaeal and bacterial amo $A$ gene abundances. At each reach, we collected a composite sample of 3 cobbles from sampling stations 1,5 , and 7 . We scraped epilithic biofilms with a sterile metallic brush and washed it into a sterile $250-\mathrm{mL}$ plastic beaker with stream water. We scraped the side of the cobble facing up (light-side) and the side facing the sediment (dark-side) separately. We estimated the surface area scraped by covering cobbles with aluminum foil and applying a massto-area relationship. We characterized epipsammic biofilms by collecting a composite sample (3 locations) of $\sim 100 \mathrm{~g}$ of sediments from the 0 - to 5 - $\mathrm{cm}$ surface layer from sampling stations 1,5 , and 7 at each reach. After mixing well, we placed a 30 -g subsample into an aluminum tray for biomass estimation.

To further examine whether biomass accrual influenced bacterial and archaeal amo $A$ gene abundance in biofilms exposed to light, we selected 10 cobbles/reach that appeared to differ in biofilm biomass and sampled light-side biofilms as previously described. We stored all samples on ice and carried them to the laboratory within $2 \mathrm{~h}$.

\section{Laboratory analyses}

We analyzed stream water samples for $\mathrm{NH}_{4}{ }^{+}, \mathrm{NO}_{2}{ }^{-}$, and $\mathrm{NO}_{3}{ }^{-}$concentrations following standard colorimetric methods (APHA 1995) on an autoanalyzer (FUTURA, Frepillon, France). We filtered a known volume of the biofilm sludge onto $0.7-\mu \mathrm{m}$ pore-size FVF glass-fiber filters (Albet) to measure chl $a$ and biomass of the epilithic biofilms. After acetone extraction, we estimated chl $a$ by spectrophotometry (ultraviolet-visible spectrometer, UV-2401PC; Shimadzu, Kyoto, Japan) and correction for phaeopigments following Steinman et al. (2006). We measured biomass of epilithic and epipsammic biofilms as ash-free dry mass (AFDM). Samples were weighed after drying at $60^{\circ} \mathrm{C}$ until constant mass ( $0.1 \mathrm{mg}$; model $\mathrm{MC1}$ analytical balance; Sartorius, Göttingen, Germany), and then reweighed after combustion at $500^{\circ} \mathrm{C}$ for $5 \mathrm{~h}$. We calculated AFDM as the difference between dry and combusted mass and reported it per unit of surface area $\left(\mathrm{g}\right.$ AFDM $\left./ \mathrm{cm}^{2}\right)$. The same AFDM units were used for epilithic and epipsammic biofilm for comparison purposes. For epipsammic biofilm, we estimated the total colonizable surface area by summing the surface area of different grain-size fractions of a previously weighed sediment sample ( 100 g). We separated grain-size fractions $>63 \mu \mathrm{m}$ by sieving and calculated surface area assuming sphericity (Horowitz 1991). We obtained the surface area of grain-size fractions $<63 \mu \mathrm{m}$ by analyzing sediment samples with a particle-size analysis counter (MasterSizer 2000; Malvern, Herrenberg, Germany).

To estimate the abundance of AOB and AOA in epilithic biofilms, we filtered $5 \mathrm{~mL}$ of well-mixed biofilm sludge through a 0.2 -mm pore-size polycarbonate membrane (Millipore, Darmstadt, Germany), air dried the filter, and placed it in lysis buffer $(40 \mathrm{mmol} / \mathrm{L}$ ethylenediaminetetra-acetic acid, $50 \mathrm{mmol} / \mathrm{L}$ Tris, $\mathrm{pH} 8.3$, and $0.75 \mathrm{~mol} / \mathrm{L}$ sucrose). For epipsammic biofilms, we weighed $\sim 1 \mathrm{~g}$ of wet sediment and placed it in lysis buffer. We extracted DNA after incubation with lysozyme, proteinase $\mathrm{K}$, and sodium dodecyl sulfate and phenol-chloroform (Hervàs and Casamayor 2009). Abundance of $\mathrm{AOA}$ and $\mathrm{AOB}$ was estimated by quantitative real time polymerase chain reaction (qPCR) with primers CrenamoA23f (5'-ATGGTCTGGCTWAGACG-3')-CrenamoA616r (5'-GCCATCCATCTGTATGTCCA-3'; Tourna et al. 2008) for AOA, and amoA1F (5'-GGGTTTCTACTGGTGGT-3')amoA2R (5'-CCCCTCKGSAAAGCCTTCTTC-3'; Rotthauwe et al. 1997) for AOB as recently reported (Merbt et al. 2011, 2015).

\section{Calculation of reach-scale metabolism}

We measured daily rates of reach-scale metabolism for 4 consecutive days at each reach. We used the 2-station method (Bott et al. 2006) to estimate daily rates of gross primary production (GPP) and ecosystem respiration (ER) by integrating changes in DO concentration between the top and bottom of the reach over $24 \mathrm{~h}$. We corrected instantaneous net DO change rates between the 2 stations for reaeration DO fluxes by calculating the product of DO deficit, reaeration coefficient, water travel time, and $Q$ (Mulholland et al. 2001). We estimated DO concentration at saturation based on average water temperature and atmospheric 
pressure provided by the DO probes. The DO deficit was estimated by comparing measured and saturation DO values. We estimated reaeration coefficients $(k)$ with the BASE (BAyesian Single-station Estimation) model following the procedure and R code published by Grace et al. (2015). The model estimates $k$ by reconstructing the diurnal cycle of DO concentration measured at a single station through $2 \times 10^{3}$ iterations after allowing the model to reach equilibrium using a Markov Chain Monte Carlo (MCMC) approach to estimate the values of each equation parameter. The goodness-of-fit of the models was evaluated on the basis of $R^{2}$, which quantifies the correlation between modeled and measured DO data, and the $\hat{R}$ statistic that indicates whether the MCMC chain of model parameters have adequately converged to a stationary distribution (Grace et al. 2015). We considered only daily models with $R^{2} \geq 0.7$ and fine MCMC convergence. Daily rates of GPP and ER can also be estimated with the BASE model, but we chose the 2-station method because the values obtained more accurately integrate the metabolic activity of the reaches where we conducted the $\mathrm{NH}_{4}{ }^{+}$-addition experiments.

The average of the instantaneous net DO change rates, corrected by reaeration fluxes, at night was extrapolated to $24 \mathrm{~h}$ to estimate daily rates of ER. We acknowledge that the assumption of constant respiration throughout the day may be unrealistic because respiration rates tend to be higher during the day than at night (Hotchkiss and Hall 2014). However, putative increases in daytime respiration are difficult to estimate from in situ DO measurements and can be highly variable among streams (from 54 to $340 \%$ ), which complicates the possibility of including differences in day- vs nighttime respiration in our calculations. Thus, our estimates of whole-reach ecosystem respiration are indicative only and might be underestimated.

We computed daily rates of GPP by integrating the difference between the instantaneous corrected net DO change rates during the day hours and the averaged instantaneous rate at night. We expressed daily rates of GPP and ER per unit of streambed area $\left(\mathrm{g} \mathrm{O}_{2} \mathrm{~m}^{-2} \mathrm{~d}^{-1}\right)$. For each reach, values of ER were available for 4 consecutive days and values of GPP only for $2 \mathrm{~d}$ because of a malfunction of DO probes during some daytime readings. We used the GPP : ER ratio as a proxy of the relative dominance of photoautotrophic activity in the reaches.

\section{Calculation of reach-scale gross and net areal $\mathrm{NH}_{4}{ }^{+}$oxidation rates}

For each sampling date and time of the day (day and night), we estimated gross $\mathrm{NH}_{4}{ }^{+}$oxidation rates from the longitudinal increase in $\mathrm{NO}_{2}{ }^{-}$concentration resulting from short-term $\mathrm{NH}_{4}{ }^{+}$constant-rate additions. We assumed that the contribution of new mineralized $\mathrm{NH}_{4}{ }^{+}$to increases in $\mathrm{NO}_{2}{ }^{-}$concentration was small because ambient $\mathrm{NO}_{2}{ }^{-}$concentration tended to decrease rather than increase along the reach. We focused on $\mathrm{NO}_{2}{ }^{-}$rather than on $\mathrm{NO}_{3}{ }^{-}$concentration because ambient concentrations were $100 \times$ lower for $\mathrm{NO}_{2}{ }^{-}$than for $\mathrm{NO}_{3}{ }^{-}$, which enabled us to estimate $\mathrm{NH}_{4}{ }^{+}$oxidation with higher accuracy. Following Webster and Valett (2006), we calculated the mass transfer coefficient of $\mathrm{NO}_{2}{ }^{-}$production $\left(k_{A O}\right.$ gross $)$ per unit of reach length (in $1 / \mathrm{m}$ ) after linearizing the $1^{\mathrm{st}}$-order equation:

$$
C_{x}=C_{t o p}\left(\frac{\operatorname{Cond}_{x}}{\operatorname{Cond}_{\text {top }}}\right) e^{k_{A O_{-} \text {gross }^{x}}}
$$

where $C$ is the plateau $\mathrm{NO}_{2}{ }^{-}$concentration corrected by ambient concentration in stream water (in $\mu \mathrm{g} \mathrm{N} / \mathrm{L}$ ), and Cond is the plateau stream water EC corrected by ambient $\mathrm{EC}$ (in $\mu \mathrm{S} / \mathrm{cm}$ ) at the top of the reach (top) and at each sampling location along the reach $(x$, in $\mathrm{m})$. We fitted linear regressions by least squares and calculated gross areal $\mathrm{NH}_{4}{ }^{+}$ oxidation rates $\left(U_{A O \_ \text {gross }}\right.$, in $\left.\mathrm{mg} \mathrm{N} \mathrm{m}^{-2} \mathrm{~h}^{-1}\right)$ only for those cases for which $k_{A O}$ gross was significant with the equation:

$$
U_{A O \_ \text {gross }}=\frac{\left(Q C_{A v g} k_{A O \_ \text {gross }}\right)}{w}
$$

where $Q$ is stream discharge, $C_{A v g}$ is the average ambient $\mathrm{NO}_{2}{ }^{-}$concentration in stream water for the 7 sampling stations, and $w$ is the average wetted width.

We estimated whole-reach net $\mathrm{NH}_{4}{ }^{+}$oxidation rates $\left(k_{A O \_n e t}\right.$ and $\left.U_{A O \_n e t}\right)$ to investigate further the dominance of $\mathrm{NH}_{4}{ }^{+}$oxidation in nitrification (i.e., $\mathrm{NH}_{4}{ }^{+}$oxidation followed by $\mathrm{NO}_{2}{ }^{-}$oxidation). We calculated $k_{A O \_n e t}$ (in $1 / \mathrm{m}$ ) and $U_{A O \text { net }}\left(\right.$ in $\mathrm{mg} \mathrm{N} \mathrm{m} \mathrm{m}^{-2} \mathrm{~h}^{-1}$ ) with Eqs 1 and 2, respectively, but substituting plateau with ambient $\mathrm{NO}_{2}{ }^{-}$concentrations (von Schiller et al. 2011). We corrected $\mathrm{NO}_{2}{ }^{-}$ concentration by ambient $\mathrm{EC}$ to account for groundwater dilution. Net $\mathrm{NH}_{4}{ }^{+}$oxidation is the balance between $\mathrm{NO}_{2}{ }^{-}$ produced by ammonia oxidizers and $\mathrm{NO}_{2}{ }^{-}$used by $\mathrm{NO}_{2}{ }^{-}$ oxidizing bacteria along the reach. Thus, we expected values of $k_{A O \_n e t} \neq 0$ (and $U_{A O \_n e t} \neq 0$ ) when $\mathrm{NH}_{4}{ }^{+}$oxidation $\left(1^{\text {st }}\right.$ nitrification step) and $\mathrm{NO}_{2}{ }^{-}$oxidation ( $2^{\text {nd }}$ nitrification step) did not counterbalance each other.

\section{Calculation of reach-scale metabolic areal $\mathrm{N}$ uptake rates}

To examine the relative contribution of $\mathrm{NH}_{4}{ }^{+}$oxidation to reach-scale $\mathrm{N}$ uptake, we used whole-reach rates of metabolism and stoichiometric principles to estimate daytime and nighttime areal $\mathrm{N}$ uptake rates (in $\mathrm{mg} \mathrm{N} \mathrm{m}^{-2} \mathrm{~h}^{-1}$ ) (Hall and Tank 2003, Webster et al. 2003). We assumed that photoautotrophic demand for $\mathrm{N}$ occurred only during the day in association with net primary production (NPP), and that NPP was 55\% of measured GPP (Hall and Beaulieu 2013). We measured $\mathrm{N}$ uptake by considering a photosynthetic quotient $=1.2$ (Webster et al. 2003) and a $\mathrm{C}: \mathrm{N}$ ratio $=$ 
7 similar to that reported for epilithic biofilms growing on the light-side of cobbles in the study stream $(\mathrm{C}: \mathrm{N}=6.9 \pm$ $0.1, n=143$; Merbt et al. 2011). We assumed that photoautotrophic and heterotrophic respiration were constant over the day and estimated heterotrophic $\mathrm{N}$ demand from respiration measurements. Heterotrophic respiration equaled ecosystem respiration minus photoautotrophic respiration (45\% of GPP) and $\mathrm{O}_{2}$ used by nitrifiers $\left(2 \mathrm{~mol}\right.$ of $\mathrm{O}_{2}=1 \mathrm{~mol}$ of $\mathrm{N}$ nitrified). We used values of $U_{A O_{-} \text {gross }}$ for estimating $\mathrm{O}_{2}$ consumed by ammonia oxidizers during day- and nighttime separately. To estimate heterotrophic $\mathrm{N}$ demand, we considered a respiratory quotient $=0.85$ (Bott 1996) and a $\mathrm{C}: \mathrm{N}$ molar ratio $=5$ (Fenchel et al. 1998). We calculated an upper and lower limit of heterotrophic $\mathrm{N}$ demand by considering a moderate and low heterotrophic production (20 and $5 \%$ of heterotrophic respiration, respectively) (Hall and Tank 2003). We calculated whole-reach metabolic N uptake by summing photoautotrophic $\mathrm{N}$ demand (only during the day), heterotrophic $\mathrm{N}$ demand, and $\mathrm{NH}_{4}{ }^{+}$oxidation either during the day or at night. The relative contribution of $\mathrm{NH}_{4}{ }^{+}$oxidation to whole-reach metabolic $\mathrm{N}$ uptake $\left(F_{A O}\right.$, in \%) was calculated by dividing $U_{A O_{-} \text {gross }}$ by whole-reach metabolic $\mathrm{N}$ uptake. We acknowledge that our approach may be an oversimplification of the potential contribution of different microorganism types to in-stream $\mathrm{N}$ uptake. In particular, we may be underestimating the contribution of ER to stream metabolism (and thus, $\mathrm{N}$ demand by heterotrophs) and overestimating the contribution of GPP to stream metabolism (and thus, photoautotrophic $\mathrm{N}$ demand) by assuming constant respiration throughout the day. Note, however, that $\mathrm{NH}_{4}{ }^{+}$oxidation rates were calculated independently of DO time series, and thus their contribution to metabolic $\mathrm{N}$ uptake may not be affected by the uncertainties associated with fractioning ER between heterotrophs and photoautotrophs.

\section{Statistical data analysis}

We tested differences in environmental conditions (mean daily PAR, stream water temperature, $\mathrm{DO}, \mathrm{NH}_{4}{ }^{+}, \mathrm{NO}_{3}{ }^{-}$, $\mathrm{NO}_{2}{ }^{-}$) between the open and shaded reach with Student's $t$-tests. Normality of the data was confirmed with the Shapiro test and variance equality with the Levene test (Zar 1996). Only DIN concentration was $\log (x)$-transformed to achieve normality requirements. Student's $t$-tests also were used to explore differences in epilithon characteristics (AFDM and chl a) between the 2 reaches. Differences in metabolism (GPP and ER) between the open and shaded reach were tested by comparing the $95 \%$ confidence intervals (CIs) obtained for the 2 data sets (Zar 1996). No Student's $t$-test was applicable in this case because the degrees of freedom were too low $(\mathrm{df}<5)$.

We explored the potential influence of light on the spatial distribution of ammonia oxidizers by testing for differences in AOA and AOB abundance between reaches (open and shaded) and among biofilm types (light-side, dark-side, and epipsammic) with a 2 -way analysis of variance (ANOVA; reach and biofilm type as fixed factors). Data were $\log (x)$ transformed to fulfill normality requirements. We further explored the potential self-shading effect of biofilms on the development of ammonia oxidizer communities by analyzing the relationship between biomass accrual (AFDM) and the total abundance of $a m o A(\mathrm{AOA}+\mathrm{AOB})$ in light-side biofilms. We expanded this analysis by including data from light-side and dark-side epilithic biofilms collected during previous studies in the same stream and forested streams nearby (Merbt et al. 2015). All samples were collected during summer, under comparable shading, temperature, and hydrological conditions to our study; thus, numbers were comparable. We applied nonlinear regression analysis and identified the best fit between AFDM and $a m o A$ abundance by least squares regression (Zar 1996).

To test for differences in $\mathrm{NH}_{4}{ }^{+}$oxidation rates between day and night, we pooled data from the open and shaded reach ( $n=4$ for each period). We used $95 \%$ CIs for each data set to analyze differences in $U_{A O_{-} \text {net }}, U_{A O_{-} \text {gross }}$, and $F_{A O}$ between day and night. All statistical analyses were run in $\mathrm{R}$ (version 3.2.2; R Project for Statistical Computing, Vienna, Austria).

\section{RESULTS \\ Environmental conditions and whole-reach stream metabolism}

During the study period, daily PAR followed a marked diel pattern at both reaches, but light intensity peaked $2 \mathrm{~h}$ earlier at the open than the shaded reach (Fig. 1A). Mean daily values of PAR were $4 \times$ higher at the open than the shaded reach (Table 1). Stream water temperature and DO peaked around midday at both reaches (Fig. 1B, C). Mean daily temperature and DO concentrations did not differ between reaches (Table 1).

Average DIN concentration was dominated by $\mathrm{NO}_{3}{ }^{-}$at both reaches (Table 1 ). $\mathrm{NH}_{4}{ }^{+}$concentration was highly variable during the experiments, but differences between reaches were not statistically significant (Table 1 ). Concentrations of $\mathrm{NO}_{3}{ }^{-}$and $\mathrm{NO}_{2}{ }^{-}$tended to be higher at the shaded than the open reach, probably because the shaded reach was closer to the WWTP effluent (Table 1).

During the study period, mean daily rates of wholereach metabolism were dominated by heterotrophic activity at both reaches. Mean ER (mean $\pm 95 \% \mathrm{CI}, 6.3 \pm 6.7 \mathrm{~g}$ $\left.\mathrm{O}_{2} \mathrm{~m}^{-2} \mathrm{~d}^{-1}\right)$ was $4 \times$ higher than GPP $\left(1.4 \pm 0.7 \mathrm{~g} \mathrm{O}_{2} \mathrm{~m}^{-2}\right.$ $\mathrm{d}^{-1}$ ), and GPP : ER averaged $0.3 \pm 0.4$. Mean daily rates of ER and GPP were similar between reaches.

\section{Streambed biofilm characteristics}

AFDM content of epipsammic biofilms was similar between reaches (Fig. 2A). For dark-side biofilms, AFDM and $\operatorname{chl} a$ content was significantly higher in the open than the 

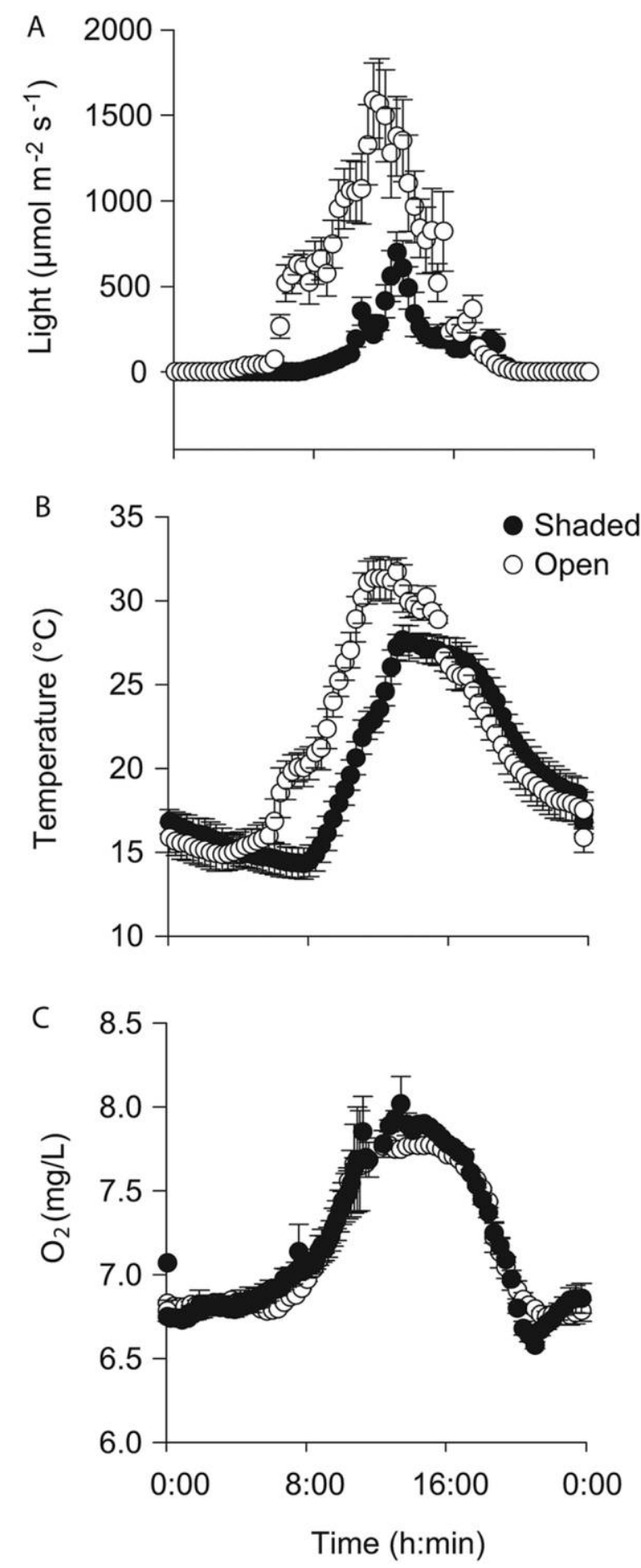

Figure 1. Mean $( \pm$ SE) photosynthetically active radiation (PAR) (A), temperature (B), and dissolved $\mathrm{O}_{2}$ concentration (DO) (C) measured at hourly intervals during the period of study at the open and shaded reaches.

shaded reach, whereas the opposite was found for lightside biofilms (Fig. 2A, B).

Reach did not affect abundance of AOA or AOB within biofilm types for the 2 types of ammonia oxidizers (2-way
ANOVA, $F<0.9, p>0.05$; Fig. 3A, B). AOA were more abundant in epipsammic than in epilithic biofilms (2-way ANOVA, $F=7.6, p=0.004)$, whereas the opposite was found for AOB (2-way ANOVA, $F=12, p=0.0004$ ). The 2 types of ammonia oxidizers were equally abundant in epipsammic biofilms (Student's $t$-test, $t=0.452, p>$ $0.05)$, whereas epilithic biofilms were colonized mostly by AOB (Student's $t$-test, dark-side biofilm: $t=-4.17, p=$ 0.009; light-side biofilm: $t=-4.73, p=0.002$ ).

The potential self-shading effect of biofilms on the development of ammonia oxidizers was explored by analyzing the relationship between $a m o A$ gene abundance and AFDM in light- and dark-side biofilms. In dark-side biofilms, the abundance of $a m o A$ gene was not related to AFDM content (Fig. 4A). In light-side biofilms, AFDM and amoA gene abundance were positively and asymptotically related. The inflection point of the curve (i.e., $2^{\text {nd }}$ derivative of the regression model) occurred at $0.17 \mathrm{mg} \mathrm{AFDM} / \mathrm{cm}^{2}$ (Fig. 4B). Above this threshold, amo $A$ gene abundance remained relatively constant around $10^{4}$ gene copies $/ \mathrm{cm}^{2}$, regardless of changes in AFDM. This result was substantiated after comparing amo $A$ gene abundance above and below this threshold (Fig. 4A, B).

\section{Whole-reach net and gross $\mathrm{NH}_{4}{ }^{+}$oxidation rates}

The values of $k_{A O \_n e t}$ were similar and negative in $87 \%$ of the cases (7 of 8) in both reaches, an indication that $\mathrm{NH}_{4}{ }^{+}$ oxidation (and especially the transformation of $\mathrm{NO}_{2}{ }^{-}$to $\mathrm{NO}_{3}{ }^{-}$) was an important piece of the $\mathrm{N}$ cycle in this stream. $U_{A O}$ net did not differ between the open $(-1.1 \pm 1.9 \mathrm{mg} \mathrm{N}$ $\left.\mathrm{m}^{-2} \mathrm{~h}^{-1}\right)$ and shaded $\left(-1.9 \pm 1.7 \mathrm{mg} \mathrm{N} \mathrm{m}^{-2} \mathrm{~h}^{-1}\right)$ reaches, and mean values tended to be lower during the day than at night (Table 2).

In all cases, $k_{A O \_ \text {gross }}$ was positive and provided evidence that $\mathrm{NH}_{4}{ }^{+}$additions stimulated gross $\mathrm{NH}_{4}{ }^{+}$oxidation and $\mathrm{NO}_{2}{ }^{-}$production. $U_{A O_{-} \text {gross }}$ did not differ between the open $\left(3.9 \pm 6.5 \mathrm{mg} \mathrm{N} \mathrm{m}^{-2} \mathrm{~h}^{-1}\right)$ and shaded $\left(14 \pm 26.4 \mathrm{mg} \mathrm{N} \mathrm{m}^{-2}\right.$ $\mathrm{h}^{-1}$ ) reaches. Mean values of $U_{A O_{\text {g gross }}}$ tended to be lower during the day than at night (Table 2).

Whole-reach metabolic $\mathrm{N}$ uptake was similar between reaches and no differences were found between day $(10.5 \pm$ $\left.5.8 \mathrm{mg} \mathrm{N} \mathrm{m}^{-2} \mathrm{~h}^{-1}\right)$ and night $\left(9.5 \pm 7.6 \mathrm{mg} \mathrm{N} \mathrm{m}^{-2} \mathrm{~h}^{-1}\right)$ (Fig. 5A). The same pattern was obtained when using either the upper or lower limit for heterotrophic growth, though values were $25 \%$ higher in the former than in the latter. The contribution of $\mathrm{NH}_{4}{ }^{+}$oxidation to whole-reach $\mathrm{N}$ uptake $\left(F_{A O}\right)$ was high $(38-89 \%)$ during the day and at night. $F_{A O}$ varied depending on the scenario of heterotrophic growth considered (Table 2). Mean $F_{A O}$ tended to be higher at night than during the day (Fig. 5B).

\section{DISCUSSION}

To assess the potential effect of natural irradiance on the structure (i.e., abundance and spatial distribution) and 
Table 1. Mean $( \pm \mathrm{SE})$ daily photosynthetic active radiation $(\mathrm{PAR})$, stream water temperature (Temp), dissolved $\mathrm{O}_{2}$ concentration (DO), and concentrations of $\mathrm{NH}_{4}{ }^{+}, \mathrm{NO}_{3}{ }^{-}$, and $\mathrm{NO}_{2}{ }^{-}$at the open and shaded reaches. The number of cases is shown in parenthesis. $p<0.05$ indicates significant difference between reaches (Student's $t$-test).

\begin{tabular}{|c|c|c|c|c|}
\hline Variable & Unit & Shaded & Open & $p$ \\
\hline PAR & $\mathrm{mol} \mathrm{m}^{-2} \mathrm{~d}^{-1}$ & $7.5 \pm 1.1(6)$ & $28.9 \pm 0.7(6)$ & $<0.01$ \\
\hline Temp & ${ }^{\circ} \mathrm{C}$ & $20 \pm 0.7(6)$ & $21.7 \pm 0.6(6)$ & 0.1 \\
\hline DO & $\mathrm{mg} \mathrm{DO} / \mathrm{L}$ & $7.17 \pm 0.34$ & $7.19 \pm 0.04$ & 0.31 \\
\hline $\mathrm{N}-\mathrm{NH}_{4}{ }^{+}$ & $\mathrm{mg} \mathrm{N} / \mathrm{L}$ & $0.14 \pm 0.11$ & $0.03 \pm 0.02$ & 0.21 \\
\hline $\mathrm{N}-\mathrm{NO}_{3}{ }^{-}$ & $\mathrm{mg} \mathrm{N} / \mathrm{L}$ & $4.10 \pm 1.21(4)$ & $2.65 \pm 0.31$ & 0.16 \\
\hline $\mathrm{N}-\mathrm{NO}_{2}{ }^{-}$ & $\mathrm{mg} \mathrm{N} / \mathrm{L}$ & $0.04 \pm 0.01$ & $0.01 \pm 0.00$ & 0.15 \\
\hline
\end{tabular}

function (i.e., $\mathrm{NH}_{4}{ }^{+}$oxidation rates) of ammonia oxidizers in an urban stream, we considered 2 reaches with contrasting canopy cover that showed substantial differences in mean daily PAR. Riparian vegetation strongly regulates light inputs reaching the stream surface, and thus, can be an important driver of stream metabolism at the reach scale (Hill et al. 1995, Matheson et al. 2012). Regarding primary producers, we found differences in chl $a$ between reaches, a result suggesting that light availability could influence their develop-

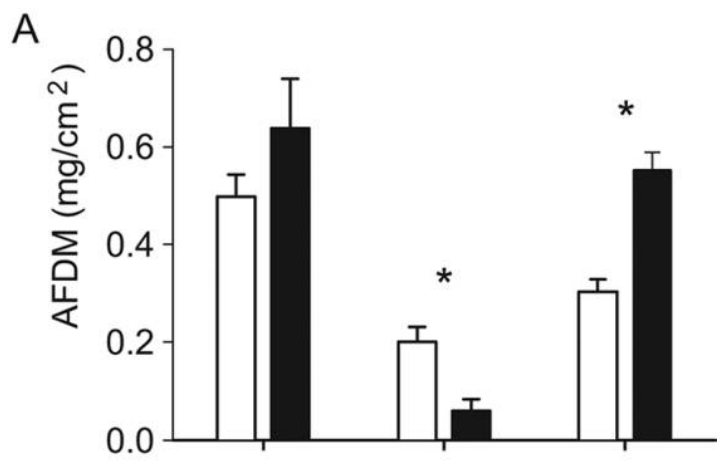

B

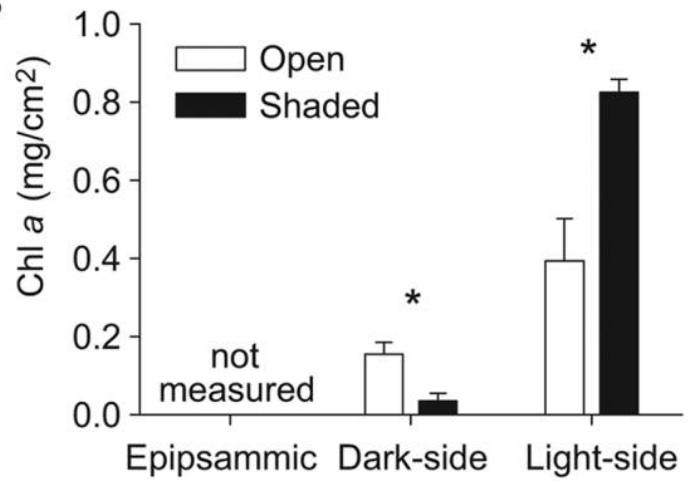

Figure 2. Mean (+SE) ash-free dry mass (AFDM) (A) and chlorophyll $a(\mathrm{chl} a)$ (B) content per colonizable area for epipsammic, dark-side, and light-side biofilms at the open and shaded reach. $n=3$ and 6 for epipsammic and epilithic biofilms, respectively. "indicates significant difference between open and shaded reaches (Student's $t$-test, $p<0.05$ ). ment within the biofilm matrix. The lowest values of $\operatorname{chl} a$ were observed at the open reach, suggesting that the photosynthetic activity at this site could be limited by the high light inputs. The response of algal communities to high levels of irradiance is complex and can vary depending on species composition and the thickness of biofilm mats (Boston and Hill 1991, Dodds et al. 1999, Laviale et al. 2009). Differences in algal taxonomic composition between reaches cannot be ruled out, but the fact that light-side epilithic biofilms at the open reach had the lowest values of AFDM suggests that these mats were thinner and more immature than those at the shaded reach, and thus, the ones more susceptible to photoinhibition (Laviale et al. 2009). Despite differences in chl $a$ and AFDM, values of GPP were similar between reaches indicating that differences in light inputs were not large enough to influence the activity of photoautotrophs at the reach scale.

In contrast to algae, the abundance of ammonia oxidizers was similar between reaches. $\mathrm{AOA}$ and $\mathrm{AOB}$ were present in similar abundance even in light-side epilithic biofilms that were more exposed to light and thus, more susceptible to photoinhibition. The failure of light to prevent ammonia oxidizers from colonizing light-exposed biofilms could be partially explained by the 3-dimensional structure of the biofilm matrix that may provide particular self-shading (Boston and Hill 1991, Guasch and Sabater 1995, Merbt et al. 2016). This idea is further supported by the nonlinear relationship between the abundance of ammonia oxidizers and biofilm AFDM, which shows that a minimal critical biomass (AFDM $>0.17 \mathrm{~g} / \mathrm{cm}^{2}$ ) is needed for successful development of ammonia oxidizers in light-side epilithic biofilms. Abundance of ammonia oxidizers in biofilms exposed to light was similar to that in dark-side biofilms at this threshold value, a result suggesting that photoinhibition was minimal (Fig. 4B). Conversely, this threshold did not hold for dark-side epilithic biofilms, which showed high abundance of ammonia oxidizers in the early stages of colonization when biofilms had low values of AFDM (Fig. 4A). Water depth and turbidity were low at both reaches, so these results suggest that the distribution of ammonia oxi- 


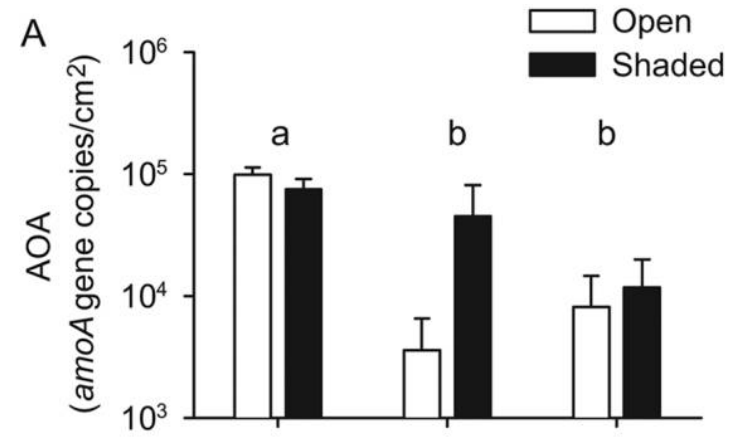

$\mathrm{B}$

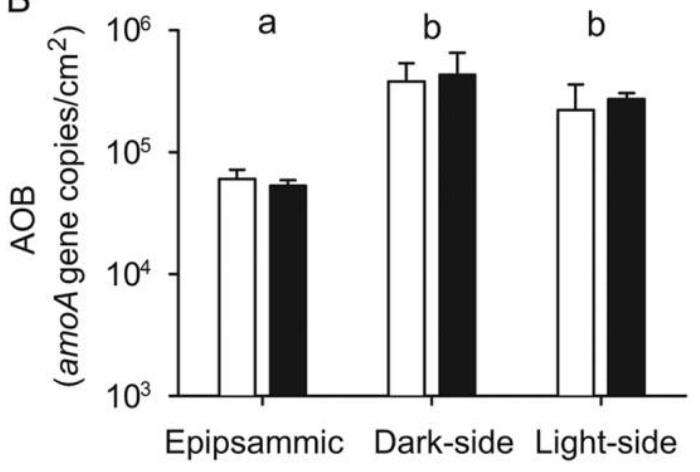

Figure 3. Mean (+SE) amoA gene abundance per colonizable area for (A) archaea (AOA) and bacteria (AOB)

(B) for epipsammic, dark-side, and light-side biofilms. $n=3$ and 6 for epipsammic and epilithic biofilms, respectively. Bars with the same letter are not significantly different (Tukey test, $p>0.05$ ). The abundances of AOA and AOB did not differ between reaches.

dizers in the stream did not respond to spatial patterns of light inputs and that all considered habitats were equally suitable for their development.

The widespread distribution of ammonia oxidizers in stream biofilms (epipsammic and epilithic) suggests that both AOA and AOB were able to overcome their intrinsic photosensitivity by developing a light-avoidance strategy. In situ ammonia oxidizers accumulated in naturally dark environments (e.g., dark-side epilithic biofilms and epipsammic biofilms) or in the biofilm matrix protected from light. This distribution may enable $\mathrm{NH}_{4}{ }^{+}$oxidation during the day (Merbt et al. 2016). In concordance, in-stream $\mathrm{NH}_{4}{ }^{+}$ oxidation rates did not differ between day and night. Moreover, decreased competition with algae for $\mathrm{NH}_{4}{ }^{+}$did not result in higher $\mathrm{NH}_{4}{ }^{+}$oxidation at night. Diel oscillations in temperature and $\mathrm{pH}$, which theoretically could influence the activity of ammonia oxidizers (Baulch et al. 2012), probably were not large enough to induce changes in $\mathrm{NH}_{4}{ }^{+}$oxidation. However, $\mathrm{NH}_{4}{ }^{+}$oxidation rates (both $k_{A O}$ net and $\left.k_{A O \_g r o s s}\right)$ were highly variable even on consecutive days at the same reach, and our sample size was too small to draw strong conclusions about the sensitivity of ammonia oxidizers to changes in environmental conditions. The high variability could be partially attributed to limitations of our methods because reach-scale $\mathrm{NH}_{4}{ }^{+}$additions were conceived for estimating gross $\mathrm{NH}_{4}{ }^{+}$uptake, which integrates both assimilatory (i.e., incorporation of $\mathrm{N}$ into biomass) and dissimilatory (i.e., nitrification) pathways, and not for estimating $\mathrm{NH}_{4}{ }^{+}$oxidation. However, we inferred $\mathrm{NH}_{4}{ }^{+}$ oxidation from the production of $\mathrm{NO}_{2}{ }^{-}$along the reach during the $\mathrm{NH}_{4}{ }^{+}$addition (not from $\mathrm{NO}_{3}{ }^{-}$production or from $\mathrm{NH}_{4}{ }^{+}$uptake itself). By focusing on $\mathrm{NO}_{2}{ }^{-}$, we minimized the potential influence of assimilatory $\mathrm{N}$ uptake and denitrification on the estimation of $\mathrm{NH}_{4}{ }^{+}$oxidation. $\mathrm{Nev}$ ertheless, additional sources of either $\mathrm{NH}_{4}{ }^{+}$or $\mathrm{NO}_{2}{ }^{-}$could lead to overestimation of $\mathrm{NO}_{2}{ }^{-}$production. For instance, rapid in-stream mineralization could have contributed to overestimation of $\mathrm{NO}_{2}{ }^{-}$production by increasing $\mathrm{NH}_{4}{ }^{+}$ availability during the addition experiment, but the influence of in-stream mineralization on stream chemistry is assumed to be low during short-term nutrient additions $(<2 \mathrm{~h})$ (Stream Solute Workshop 1990). Groundwater inputs also could influence stream water chemistry especially during wet periods and in streams with high hydrological connec-
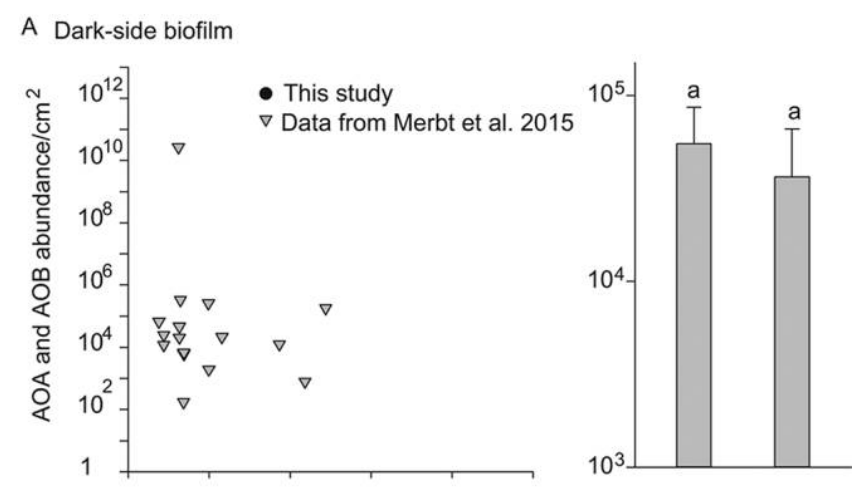

B Light-side biofilm
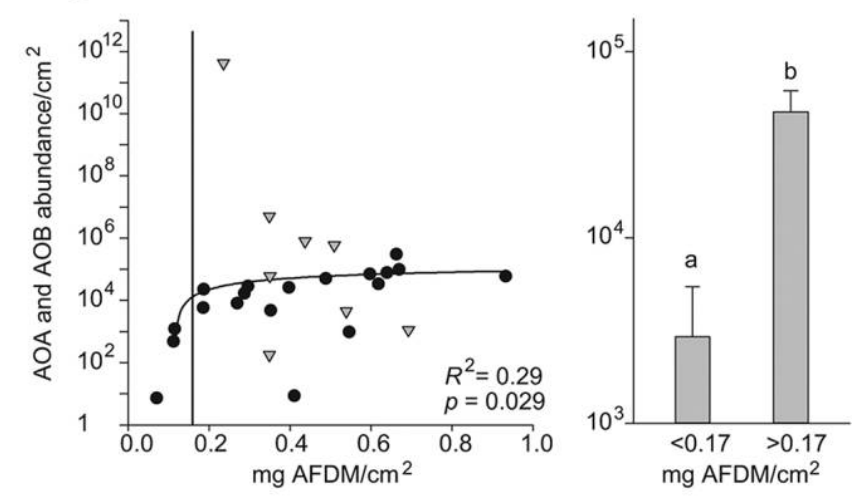

Figure 4. amoA gene abundance for archaea and bacteria $(\mathrm{AOA}+\mathrm{AOB})$ vs biofilm biomass (as ash-free dry mass [AFDM]) in dark-side (A) and light-side biofilms (B). The curve in (B) shows the best fit between the 2 variables (logarithmic model, $R^{2}=0.29$, $p=0.029$ ). The inflection point of the curve was $0.17 \mathrm{mg}$ $\mathrm{AFDM} / \mathrm{cm}^{2}$ (vertical line). The bar plots show mean $(+\mathrm{SE})$ abundance of AOA and AOB abundance $/ \mathrm{cm}^{2}$ below and above the inflection point. Bars with the same letters are not significantly different between groups (Student's $t$-test, $p>0.05$ ). 
Table 2. Mean $( \pm 95 \% \mathrm{CI})$ whole-reach areal net $\left(U_{A O_{-} n e t}\right)$ and gross $\left(U_{A O_{-} \text {gross }}\right) \mathrm{NH}_{4}{ }^{+}$oxidation rates at the study stream during the day and at night. $U_{A O_{-} n e t}$ is $<0$ and $U_{A O_{\text {g gross }}}$ is $>0$ because stream $\mathrm{NO}_{2}{ }^{-}$concentrations at ambient and plateau conditions tended to decrease and increase along the reach, respectively. The relative contribution of $U_{A O_{-} \text {gross }}$ to whole-reach $\mathrm{N}$ uptake $\left(F_{A O}\right)$ is shown for considered lower- and upper-limit scenarios (heterotrophic growth 20 and 5\%, respectively). Data from the open and shaded reaches were pooled. $n=4$ for each time of day.

\begin{tabular}{lrc}
\hline \multicolumn{1}{c}{ Variable } & \multicolumn{1}{c}{ Day } & \multicolumn{1}{c}{ Night } \\
\hline$U_{A O \_ \text {net }}\left(\mathrm{mg} \mathrm{N} \mathrm{m}^{-2} \mathrm{~h}^{-1}\right)$ & $-0.7 \pm 1.3$ & $-2 \pm 2.1$ \\
$U_{A O \_ \text {gross }}\left(\mathrm{mg} \mathrm{N} \mathrm{m}^{-2} \mathrm{~h}^{-1}\right)$ & $4 \pm 4.7$ & $14.4 \pm 26.3$ \\
$\mathrm{~F}_{\mathrm{AO}}(\%)$ & & \\
$\quad$ Lower limit & $37.9 \pm 30.4$ & $67.6 \pm 35.2$ \\
$\quad$ Upper limit & $49.3 \pm 35.7$ & $89.3 \pm 14.6$ \\
\hline
\end{tabular}

tivity. However, in our case, groundwater inputs probably were negligible because the study stream tends to lose water under dry summer conditions.

Overall, ammonia oxidizers were found in the 3 types of biofilms and at both stream reaches (i.e., open and shaded), results that suggest a strong potential for $\mathrm{NH}_{4}{ }^{+}$oxidation along the stream, regardless of in situ irradiance conditions. We found that $\mathrm{NH}_{4}{ }^{+}$oxidation was occurring actively in the study reaches as indicated by the longitudinal decrease

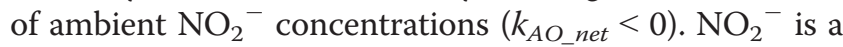
very bioreactive form of inorganic $\mathrm{N}$ that is transformed rapidly to $\mathrm{NO}_{3}{ }^{-}$, and thus, usually is found in very small concentrations in more pristine environments (Peterson et al. 2001). Detection of reach-scale net $\mathrm{NO}_{2}{ }^{-}$uptake in the study stream suggests that: 1) $\mathrm{NH}_{4}{ }^{+}$oxidation was occurring, 2) substrate for $\mathrm{NH}_{4}{ }^{+}$oxidation $\left(\mathrm{NH}_{4}{ }^{+}\right)$was not limiting, and 2) the $\mathrm{NO}_{2}{ }^{-}$produced was immediately oxidized to $\mathrm{NO}_{3}{ }^{-}$. Simultaneous longitudinal changes in stream $\mathrm{NO}_{3}{ }^{-}$concentrations were not detected because either increases associated with $\mathrm{NO}_{2}{ }^{-}$uptake were too small (4$50 \mu \mathrm{g} \mathrm{N} / \mathrm{L}$ ) compared to ambient $\mathrm{NO}_{3}{ }^{-}$concentration (2$5 \mathrm{mg} \mathrm{N} / \mathrm{L}$ ) or increases in $\mathrm{NO}_{3}{ }^{-}$were counterbalanced by other uptake and release processes. Short-term $\mathrm{NH}_{4}{ }^{+}$additions indicated that the microbial community had the capacity to process additional $\mathrm{NH}_{4}{ }^{+}$inputs, and stoichiometric calculations suggested that the stream's potential for $\mathrm{NH}_{4}{ }^{+}$oxidation could account for up to $89 \%$ of reach-scale $\mathrm{N}$ uptake. This value should be taken with caution because uncertainty is large when calculating in-stream $\mathrm{N}$ uptake from whole-reach metabolic rates that strongly depend on estimation of the reaeration coefficient (Aristegi et al. 2009). Future studies based on stable isotope tracers $\left({ }^{15} \mathrm{NH}_{4}{ }^{+}\right)$ would shed more light on the contribution of $\mathrm{NH}_{4}{ }^{+}$oxidation to $\mathrm{NH}_{4}{ }^{+}$uptake (Mulholland et al. 2000). This information would be complementary to our study because addition of ${ }^{15} \mathrm{NH}_{4}{ }^{+}$to the stream complicates the possibility of calculating $\mathrm{N}$ cycling rates on consecutive reaches and consecutive days.

Previous investigators have shown that microbial $\mathrm{NH}_{4}{ }^{+}$ oxidation plays a pivotal role in the $\mathrm{N}$ cycle of humanaffected streams receiving WWTP inputs (Groffman et al. 2005, Merseburger et al. 2005, Ribot et al. 2012, Merbt et al. 2015), and our results are in agreement with these findings. The high potential for $\mathrm{NH}_{4}{ }^{+}$oxidation in reaches downstream of WWTP inputs has been explained by higher substrate availability and temperature in reaches down- than upstream of WWTPs (Merseburger et al. 2005, Tourna et al. 2008). Inputs of dissolved organic $C$ from the WWTP can also contribute to $\mathrm{NH}_{4}{ }^{+}$oxidation by enhancing mineralization, which in turn increases $\mathrm{NH}_{4}{ }^{+}$availability (Bernhardt and Likens 2002, Daniel et al. 2002, Teissier et al. 2007). Moreover, high nutrient loads can increase biofilm growth and thickness (Merbt et al. 2011), thereby enhancing the light-protective effect of those biofilms. These environmental conditions and constant inoculation of allochthonous nitrifying organisms from the WWTP (Mussman et al. 2013,

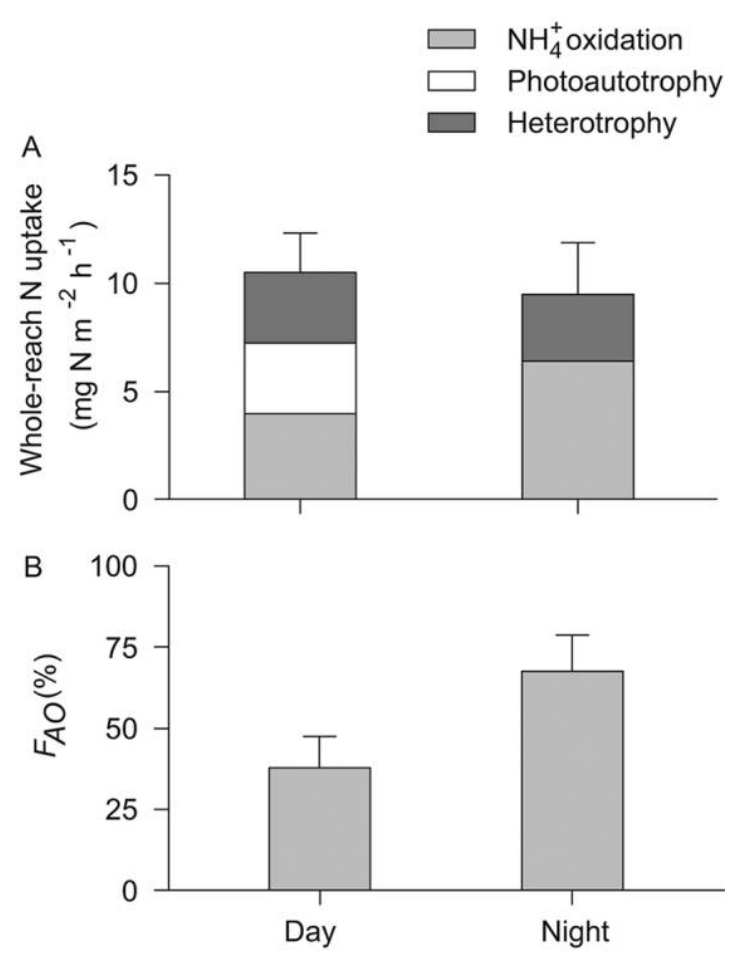

Figure 5. A.-Mean $(+\mathrm{SE})$ whole-reach metabolic $\mathrm{N}$ uptake for day- and nighttime at the Santa Maria de Palautordera stream (open and shaded reach data pooled). Photoautotrophic and heterotrophic assimilatory $\mathrm{N}$ demand was calculated from stoichiometric principles. $\mathrm{N}$ uptake by nitrifiers was based on in situ measurements during short-term constant rate $\mathrm{NH}_{4}{ }^{+}$ additions. B.-Mean (+SE) relative contribution of $\mathrm{NH}_{4}{ }^{+}$oxidation to whole-reach $\mathrm{N}$ uptake $\left(F_{A O}\right)$. Values correspond to the upper-limit scenario for $\mathrm{NH}_{4}{ }^{+}$oxidation (low heterotrophic growth). $n=4$. 
Merbt et al. 2015) probably help sustain $\mathrm{NH}_{4}{ }^{+}$oxidation, turning these types of streams into nitrifying hotspots that act as natural prolongations of the wastewater treatment process (Merseburger et al. 2005). Our findings agree with findings by others that the inputs from WWTP effluents (nutrients, organic matter, and microbes) have a strong effect on stream functioning and can shift overall stream metabolism and nutrient cycling (Martí et al. 2004, Gücker et al. 2006).

Despite differences in irradiance, we found similar abundance of ammonia oxidizers in the 2 study reaches and high $\mathrm{NH}_{4}{ }^{+}$oxidation rates during both day and night. These findings suggest that the environmental conditions prevailing in urban streams can be more influential than the potential inhibitory effect of irradiance on the distribution and activity of ammonia oxidizers. The lack of consistent photoinhibition effects on the distribution of ammonia oxidizers and ecosystem-scale microbial nitrification shows that light is not a critical regulating factor of the spatial distribution of AOA and AOB or of reach-scale $\mathrm{NH}_{4}{ }^{+}$oxidation in highly N-loaded streams. Thus, paradigms like inhibition of ammonia oxidizers by light do not always hold under in situ conditions where other factors, such as biofilm self-shading, can come into play.

\section{ACKNOWLEDGEMENTS}

Author contributions: All authors contributed equally to the study design. SB, SNM, and MR conducted field work. SNM conducted molecular analysis. SNM and SB analyzed data and wrote the manuscript with contributions from MR, EM, and EOC.

We thank A. Serra, C. Romero, J. Gonzalez, and C. Alvarez for excellent field assistance. This research was granted by DARKNESS CGL2012-32747 to EOC, MED_FORESTREAM CGL201130590-CO2-02 (MINECO) and REFRESH-244121 ( $7^{\text {th }}$ Framework Programme European Union Commission) to EM and SB, and NICUS (CGL-2014-55234-JIN) to SB. SNM was supported by the predoctoral fellowship of the program Junta para la Ampliación de Estudios (JAE) from the Spanish National Research Council (CSIC).

\section{LITERATURE CITED}

APHA (American Public Health Association). 1995. Standard methods for the examination of water and wastewater. $19^{\text {th }}$ edition. American Public Health Association, American Water Works Association, and Water Environment Federation, Washington, DC.

Aristegi, L., O. Izagirre, and A. Elosegi. 2009. Comparison of several methods to calculate reaeration in streams, and their effects on estimation of metabolism. Hydrobiologia 635:113124.

Baulch, H. M., P. J. Dillon, R. Maranger, J. J. Venkiteswaran, H. F. Wilson, and S. L. Schiff. 2012. Night and day: short-term variation in nitrogen chemistry and nitrous oxide emissions from streams. Freshwater Biology 57:509-525.

Beman, J. M., B. N. Popp, and S. E. Alford. 2012. Quantification of ammonia oxidation rates and ammonia-oxidizing archaea and bacteria at high resolution in the Gulf of California and eastern tropical North Pacific Ocean. Limnology and Oceanography 57:711-726.

Bernhardt, E. S., and G. E. Likens. 2002. Dissolved organic carbon enrichment alters nitrogen dynamics in a forest stream. Ecology 83:1689-1700.

Boston, H., and W. Hill. 1991. Photosynthesis-light relations of stream periphyton communities. Limnology and Oceanography 36:644-656.

Bott, T. L. 1996. Primary productivity and community respiration. Pages 533-556 in F. R. Hauer and G. A. Lamberti (editors). Methods in stream ecology. Academic Press, San Francisco, California.

Bott, T. L., J. D. Newbold, and D. B. Arscott. 2006. Ecosystem metabolism in Piedmont streams: reach geomorphology modulates the influence of riparian vegetation. Ecosystems 9:398-421.

Daniel, M. H. B., A. A. Montebelo, M. C. Bernardes, J. P. Ometto, P. B. de Camargo, A. V. Krusche, M. V. Ballester, R. L. Victoria, and L. A. Martinelli. 2002. Effects of urban sewage on dissolved oxygen, dissolved inorganic and organic carbon, and electrical conductivity of small streams along a gradient of urbanization in the Piracicaba River Basin. Water, Air, and Soil Pollution 136:189-206.

Dodds, W. K., B. J. Biggs, and R. L. Lowe. 1999. Photosynthesisirradiance patterns in benthic microalgae: variations as a function of assemblage thickness and community structure. Journal of Phycology 35:42-53.

Fenchel, T. M., G. M. King, and T. H. Blackburn. 1998. Bacterial biogeochemistry: ecology of mineral cycling. Academic Press, London, UK.

Fernández-Guerra, A., and E. O. Casamayor. 2012. Habitatassociated phylogenetic community patterns of microbial ammonia oxidizers. PLoS ONE 7:e47330.

French, E., J. A. Kozlowski, M. Mukherjee, G. Bullerjahn, and A. Bollmann. 2012. Ecophysiological characterization of ammoniaoxidizing archaea and bacteria from freshwater. Applied and Environmental Microbiology 78:5773-5780.

Gammons, C. H., J. N. Babcock, S. R. Parker, and S. R. Poulson. 2011. Diel cycling and stable isotopes of dissolved oxygen, dissolved inorganic carbon, and nitrogenous species in a stream receiving treated municipal sewage. Chemical Geology 283: $44-55$.

Gordon, N. D., T. A. McMahon, and B. L. Finlayson. 2004. How to have a field day and still collect some useful information. Pages 127-214 in N. D. Gordon, T. A. McMahon, B. L. Finlayson, C. J. Gippel, and R. J. Nathan (editors). Stream hydrology, an introduction for ecologists. $2^{\text {nd }}$ edition. John Wiley and Sons, Chichester, UK.

Grace, M. R., D. P. Giling, S. Hladyz, V. Caron, R. M. Thompson, and R. Mac Nally. 2015. Fat processing of diel oxygen curves: estimating stream metabolism with BASE (Bayesian singlestation estimation). Limnology and Oceanography: Methods 13:103-114.

Groffman, P. M., A. M. Dorsey, and P. M. Mayer. 2005. N processing within geomorphic structures in urban streams. Journal of the North American Benthological Society 24:613-625.

Guasch, H., and S. Sabater. 1995. Seasonal variation in photosynthesisirradiance response by biofilms in mediterranean streams. Journal of Phycology 31:727-735. 
Gücker, B., M. Braun, and M. T. Pusch. 2006. Effects of wastewater treatment plant discharge on ecosystem structure and function of lowland streams. Journal of the North American Benthological Society 25:313-329.

Hall, R. O., and J. J. Beaulieu. 2013. Estimating autotrophic respiration in streams using daily metabolism data. Freshwater Science 32:507-516.

Hall, R. O., and J. L. Tank. 2003. Ecosystem metabolism controls nitrogen uptake in streams in Grand Teton National Park, Wyoming. Limnology and Oceanography 48:1120-1128.

Hervàs, A., and E. O. Casamayor. 2009. High similarity between bacterioneuston and airborne bacterial community compositions in a high mountain lake area. FEMS Microbiology Ecology 67:219-228.

Hill, W. R., M. G. Ryon, and E. M. Schilling. 1995. Light limitation in a stream ecosystem: responses by primary producers and consumers. Ecology 76:1297-1309.

Horowitz, A. J. 1991. A primer on sediment-trace element chemistry. $2^{\text {nd }}$ edition. US Geological Survey, Denver, Colorado.

Hotchkiss, E. R., and R. O. Hall. 2014. High rates of daytime respiration in three streams: use of $\delta^{18} \mathrm{O}_{\mathrm{O} 2}$ and $\mathrm{O}_{2}$ to model diel ecosystems metabolism. Limnology and Oceanography 59:798810.

Hyman, M. R., and D. Arp. 1992. ${ }^{14} \mathrm{C}_{2} \mathrm{H}_{2}$-and ${ }^{14} \mathrm{CO}_{2}$-labeling studies of the de novo synthesis of polypeptides by Nitrosomonas europaea during recovery from acetylene and light inactivation of ammonia monooxygenase. Journal of Biological Chemistry 267:1534-1545.

Laviale, M., J. Prygiel, Y. Lemoine, A. Courseaux, and A. Creach. 2009. Stream periphyton photoacclimation response in field conditions: effect of community development and seasonal changes. Journal of Phycology 45:1072-1082.

Lomas, M. W., and F. Lipschultz. 2006. Forming the primary nitrite maximum: nitrifiers or phytoplankton? Limnology and Oceanography 51:2453-2467.

Lupon, A., E. Martí, F. Sabater, and S. Bernal. 2016. Green light: gross primary production influences seasonal stream $\mathrm{N}$ export by controlling fine-scale $\mathrm{N}$ dynamics. Ecology 97:133-144.

Martí, E., J. Aumatell, L. Godé, M. Poch, and F. Sabater. 2004. Nutrient retention efficiency in streams receiving inputs from wastewater treatment plants. Journal of Environmental Quality 33:285-293.

Martí, E., and F. Sabater. 1996. High variability in temporal and spatial nutrient retention in Mediterranean streams. Ecology 77:854-869.

Matheson, F. E., J. M. Quinn, and M. L. Martin. 2012. Effects of irradiance on diel and seasonal patterns of nutrient uptake by stream periphyton. Freshwater Biology 57:1617-1630.

Merbt, S. N., J. C. Auguet, A. Blesa, E. Martí, and E. O. Casamayor. 2015. Wastewater treatment plant effluents change abundance and composition of ammonia-oxidizing microorganisms in mediterranean urban stream biofilms. Microbial Ecology 69: 66-74.

Merbt, S. N., J. C. Auguet, E. O. Casamayor, and E. Martí. 2011. Biofilm recovery in a wastewater treatment plant-influenced stream and spatial segregation of ammonia-oxidizing microbial populations. Limnology and Oceanography 56:1054-1064.

Merbt, S. N., S. Bernal, L. Proia, E. Martí, and E. O. Casamayor. 2016. Photoinhibition on natural ammonia oxidizers biofilm populations and implications for nitrogen uptake in stream biofilms. Limnology and Oceanography. doi:10.1002/lno.10436

Merbt, S. N., D. A. Stahl, E. O. Casamayor, E. Martí, G. W. Nicol, and J. I. Prosser. 2012. Differential photoinhibition of bacterial and archaeal ammonia oxidation. FEMS Microbiology Letters 327:41-46.

Merseburger, G. C., E. Martí, and F. Sabater. 2005. Net changes in nutrient concentrations below a point source input in two streams draining catchments with contrasting land uses. Science of the Total Environment 347:217-229.

Mulholland, P. J., C. S. Fellows, J. L. Tank, N. B. Grimm, J. R. Webster, S. K. Hamilton, E. Martí, L. Ashkenas, W. B. Bowden, W. K. Dodds, W. H. McDowell, M. J. Paul, and B. J. Peterson. 2001. Inter-biome comparison of factors controlling stream metabolism. Freshwater Biology 46:1503-1517.

Mulholland, P. J., J. L. Tank, D. M. Sanzone, W. M. Wollheim, B. J. Peterson, J. R. Webster, and J. L. Meyer. 2000. Nitrogen cycling in a forest stream determined by a ${ }^{15} \mathrm{~N}$ tracer addition. Ecological Monographs 70:471-493.

Mulholland, P. J., S. A. Thomas, H. M. Valett, J. R. Webster, and J. Beaulieu. 2006. Effects of light on $\mathrm{NO}_{3}$-uptake in small forested streams: diurnal and day-to-day variations. Journal of the North American Benthological Society 25:583-595.

Mussmann M., M. Ribot, D. von Schiller, S. N. Merbt, C. Augspurger, C. Karwautz, M. Winkel, T. J. Battin, E. Martí, and H. Daims. 2013. Colonization of freshwater biofilms by nitrifying bacteria from activated sludge. FEMS Microbial Ecology 85:104-115.

Nelson, D., and H. L. Conway. 1979. Effects of the light regime on nutrient assimilation by phytoplankton in the Baja California and northwest Africa upwelling systems. Journal of Marine Research 37:301-318.

Peterson, B. J., W. M. Wollheim, P. J. Mulholland, J. R. Webster, J. L. Meyer, J. L. Tank, E., Martí, W. B. Bowden, H. M. Valett, and A. E. Hershey. 2001. Control of nitrogen export from watersheds by headwater streams. Science 292:86-90.

Reuter, J. E., S. L. Loeb, and C. R. Goldman. 1986. Inorganic nitrogen uptake by epilithic periphyton in a $\mathrm{N}$-deficient lake. Limnology and Oceanography 31:149-160.

Ribot, M., E. Martí, D. von Schiller, F. Sabater, H. Daims, and T. J. Battin. 2012. Nitrogen processing and the role of epilithic biofilms downstream of a wastewater treatment plant. Freshwater Science 31:1057-1069.

Risgaard-Petersen, N., M. H. Nicolaisen, N. P. Revsbech, and B. A. Lomstein. 2004. Competition between ammonia-oxidizing bacteria and benthic microalgae. Applied and Environmental Microbiology 70:5528-5537.

Rotthauwe, J. H., K. P. Witzel, and W. Liesack. 1997. The ammonia monooxygenase structural gene $a m o A$ as a functional marker: molecular fine-scale analysis of natural ammonia oxidizing populations. Applied and Environmental Microbiology 63:4704-4712.

Sabater, F., A. Butturini, E. Martí, I. Muñoz, A. Romaní, J. Wray, and S. Sabater. 2000. Effects of riparian vegetation removal on nutrient retention in a Mediterranean stream. Journal of the North American Benthological Society 19:609-620.

Shears, J. H., and P. Wood. 1985. Spectroscopic evidence for a photosensitive oxygenated state of ammonia mono-oxygenase. Biochemical Journal 226:499-507. 
Small, G. E., G. S. Bullerjahn, R. W. Sterner, B. F. Beall, S. Brovold, J. C. Finlay, R. M. L. McKay, and M. Mukherjee. 2013. Rates and controls of ammonium oxidation in a large oligotrophic lake. Limnology and Oceanography 58:276-286.

Smith, J. M., F. P. Chavez, and C. A. Francis. 2014. Ammonium uptake by phytoplankton regulates nitrification in the sunlit ocean. PLoS ONE 9:e108173.

Sonthiphand, P., E. Cejudo, S. L. Schiff, and J. D. Neufeld. 2013. Wastewater effluent impacts ammonia-oxidizing prokaryotes of the Grand River, Canada. Applied and Environmental Microbiology 79:7454-7465.

Steinman, A. D., G. A. Lamberti, and P. R. Leavitt. 2006. Biomass and pigments of benthic algae. Pages 357-380 in F. R. Hauer and G. A. Lamberti (editors). Methods in stream ecology. Academic Press, San Francisco, California.

Stream Solute Workshop. 1990. Concepts and methods for assessing solute dynamics in stream ecosystems. Journal of the North American Benthological Society 9:95-119.

Teissier, S., M. Torre, F. Delmas, and F. Garabétian. 2007. Detailing biogeochemical $\mathrm{N}$ budgets in riverine epilithic biofilms. Journal of the North American Benthological Society 26:178190.

Tourna, M., T. E. Freitag, G. W. Nicol, and J. I. Prosser. 2008. Growth, activity and temperature responses of ammonia-oxidizing archaea and bacteria in soil microcosms. Environmental Microbiology 10:1357-1364.

von Schiller, D., V. Acuña, D. Graeber, E. Martí, M. Ribot, S. Sabater, X. Timoner, and K. Tockner. 2011. Contraction, fragmentation and expansion dynamics determine nutrient availability in a Mediterranean forest stream. Aquatic Sciences 73: 485-497. von Schiller, D., E. Martí, J. L. Riera, M. Ribot, A. Argerich, P. Fonollà, and F. Sabater. 2008. Inter-annual, annual, and seasonal variation of $\mathrm{P}$ and $\mathrm{N}$ retention in a perennial and an intermittent stream. Ecosystems 11:670-687.

Walker, C. B., J. R. de la Torre, M. G. Klotz, H. Urakawa, N. Pinel, D. J. Arp, C. Brochier-Armanet, P. S. G. Chain, P. P. Chan, and A. Gollabgir, J. Hemp, M. Hügler, E. A. Karr, M. Könneke, M. Shin, T. J. Lawton, T. Lowe, W. Martens-Habbena, L. A. Sayavedra-Soto, D. Lang, S. M. Sievert, A. C. Rosenzweig, G. Manning, and D. A. Stahl. 2010. Nitrosopumilus maritimus genome reveals unique mechanisms for nitrification and autotrophy in globally distributed marine crenarchaea. Proceedings of the National Academy of Sciences of the United States of America 107:8818-8823.

Warwick, J. J. 1986. Diel variation of in-stream nitrification. Water Research 20:1325-1332.

Webster, J. R., P. J. Mulholland, J. L. Tank, H. M. Valett, W. K. Dodds, B. J. Peterson, W. B. Bowden, C. N. Dahm, S. Findlay, S. V. Gregory, N. B. Grimm, S. K. Hamilton, S. L. Johnson, E. Martí, W. H. McDowell, J. L. Meyer, D. D. Morrall, S. A. Thomas, and W. M. Wollheim. 2003. Factors affecting ammonium uptake in streams: an interbiome perspective. Freshwater Biology 48:1329-1352.

Webster, J. R., and H. M. Valett. 2006. Solute dynamics. Pages 169-185 in F. R. Hauer and G. E. Lamberti (editors). Methods in stream ecology. Academic Press, San Francisco, California.

Writer, J. H., S. K. Keefe, J. N. Ryan, I. Ferrer, M. E. Thurman, and L. B. Barber. 2011. Methods for evaluating in-stream attenuation of trace organic compounds. Applied Geochemistry 26:344-345.

Zar, J. H. 1996. Biostatistical analysis. Prentice-Hall, Upper Saddle River, New Jersey. 